is known to be uncommon (S. Afr. J. Med. Sci., 25, Nos. 2 and 3 ; September 1960). They have endeavoured to record : (1) the histological reactions observed in the coronary arteries at successive age periods from birth to more than sixty years in the Portuguese East African in Lourenço Marques; (2) to type the reactions in a way which will make future comparison between these and reactions in the coronary arteries of peoples elsewhere in the world; and (3) to assess the significance of these reactions for the development of severe coronary artery disease and thrombosis.

\section{Distribution of British Reptiles and Amphibians}

A PAPER by R. H. R. Taylor on the distribution of Reptiles and Amphibians in the British Isles was first published in the British Journal of Herpetology in June 1948 (1, No. 1). In this paper, a complete record of the occurrence of the different species in the British Isles and Channel Isles was presented. It is proposed to re-write the paper and include records up to the end of 1960 . To obtain a complete and accurate picture of the present distribution, up-todate records from all areas are required. For $\mathbf{4 0}$ or 50 years there have been no published records of even the commonest species from a number of vicecounties. Lieut.-Colonel Taylor is anxious to obtain information about the following species: Anguis fragilis (slow worm); Lacerta vivipara (viviparous lizard); Lacerta agilis (sand lizard); Coronella austriaca (smooth snake); Vipera berus (viper or adder); Natrix natrix (grass or ringed snake); Triturus helveticus (palmate nowt); Triturus cristatus (great crested or warty newt); Triturus vulgaris (smooth newt); Bufo calamita (natterjack); Bufo bufo (common toad); Rana temporaria (common frog) ; Rana ridibunda (marsh frog); and Rana esculenta (edible frog). The records should show the year the species were observed and the locality. Any data should be sent to Lieut.-Colonel R. H. R. Taylor, The Studio, Belchamp St. Paul, Sudbury, Norfolk.

\section{Dependence of Photosynthesis on Temperature in Higher Plants}

IN a paper entitled "Studies of Climatic Ecotypes in Higher Plants : the Temperature Dependence of Apparent Photosynthesis in Different Populations of Solidago virgaurea", O. Bjorkman, C. Florell and P. Holmgren (Kungl. Lantbruckshögskolans Annaler, 26, $1 ; 1960)$ present results of a study of the temperature dependence of apparent assimilation in plants from different populations. Clonal material was obtained from different climatic zones, ranging from Skåne in south Sweden to Finmark in north Norway, and grown in a phytotron in chambers maintained at three different climates (alpine, continental and maritime). The climates reproduced in the chambers were based on 20-year meteorological records. Some populations were also grown under constant day and night temperatures $\left(18^{\circ} \mathrm{C}\right.$. and $8^{\circ} \mathrm{C}$. respectively) with a photoperiod of $18 \mathrm{hr}$. The apparent photosynthesis of intact plants was measured. The ecotypes were found to vary in chlorophyll content, but these differences were not correlated with values of apparent photosynthesis. The optimum temperature for photosynthesis of plants from a maritime habitat in south Sweden was $20^{\circ} \mathrm{C}$, irrespective of the climate in which they were grown. Plants from an alpine region in north Norway, on the other hand, with a few exceptions, had an optimum temperature of $16^{\circ} \mathrm{C}$. in all three climates. By contrast plants from an inland region of central Sweden were more variable. The results show a good correlation with the temperature conditions during the growing season of the three localities, and there appears to be a physiological adaptation to the temperature conditions which is under genetical control. With plants grown under constant day and night conditions some differences were found, but not as obvious as those in the climate series.

\section{Synoptic Auroral Maps}

AT the Antaretic Division of the Department of External Affairs, Melbourne, Major F. R. Bond and Dr. F. Jacka have undertaken the compilation of synoptic maps showing, at quarter hourly intervals, the plan position of auroras observed in the southern hemisphere during the International Geophysical Year. So far, only the data from Australia and the antarctic stations of Australia, Franco, Belgium and New Zealand have been plotted. With such maps it has been possible to make an estimate of the location of the isoaurore of maximum frequency of occurrence of auroras (Aust. J. Phys., 13, 610; 1960), and to make a general study of the development of auroral displays and associated magnetic disturbance on the equatorwards side of the auroral zone (Aust. J. Phys., $13,477 ; 1960)$. But on some occasions of intense magnetic disturbance $(K p=8$ or 9$)$ the aurora, for many hours, takes the form of an extensive red 'diffuse surface' over polar-cap stations. At present the synoptic maps are not complete enough to establish the extent of these 'surfaces' nor are any measurements of their height available. However, it is thought that on these occasions the electric current which gives rise to magnetic disturbance is in the nature of a continuous sheet rather than of filamentary structure as soems usual (Aust. J. Phys., 14 ; March 1961). G. Weill and Mlle. S. Huille, of France, and Mlle. P. Doyen, of Belgium, have co-operated with Messrs. Bond and Jacka in the task of compiling these maps, and the co-operation is now invited of other workers concerned with the study of southern hemisphere auroral data.

\section{Engineering Aspects of Lubrication}

The Imperial College of Science and Technology is organizing a short postgraduate full-time course on "Engineering Aspects of Lubrication" during May 1-19. This will be an intensive course covering the subject from the engineering aspect, including theories of fluid film, thin-film lubrication, wear of lubricants, lubricating materials, the properties of natural and synthetic oils, etc. The number of participants for the course will be limited to thirty-two and the fee will be 25 guineas. Further information can be obtained from the Registrar, Imperial College of Science and Technology, London, S.W.7.

\section{The British Institute of Radiology: Annual Congress}

THE annual congress and exhibition of the British Institute of Radiology is to be held jointly at the Central Hall and Church House, Westminster, London, W.C.1, during April 26-28. A number of symposia are to be included in the programme : "Localization using Physical Devices, Radioisotopes and Radiographic Methods" (April 26, at the Central Hall); "The Age Factor in the Susceptibility of 